\section{The influence of learning strategy resolution based toward environmental health learning result observed by students' concept}

Sumantri, Mohamad Syarif $\bowtie$

State University of Jakarta, Indonesia (syarifsumantri@yahoo.com)

Supendi

State University of Jakarta, Indonesia (sdntuguselatan@yahoo.co.id)

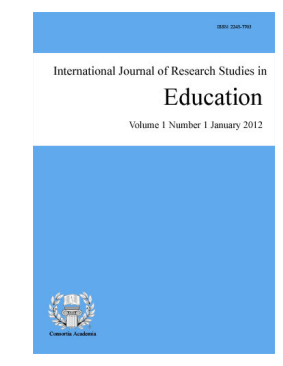

ISSN: 2243-7703 Online ISSN: 2243-7711

OPEN ACCESS

\title{
Abstract
}

The objective of this research was to know the effect of learning strategy and self-concept toward the environmental learning result about recyclable Garbage in a public elementary school, SDN 1 Tugu Selatan, North Jakarta. This research applied true experimental design with posttest-only control design. Population of the research covered all sixth grade-students of 2012/2013 whereas samples included students of class VIB as experimental (PBL) and of class VIA as control (Expository). Learning outcome of environmental health education test and self-concept scale questionnaire was employed as instruments of the research. Quantitative data consisting of score knowledge about waste recycling and self-concept scale questionnaire was collected on February until April 2012. Data was analyzed by linear variant statistical analysis (ANOVA), continued with Tukey test. Result of the research indicates that PBL does exist in the knowledge about waste recycling. Students with PBL have higher value of knowledge than those with expository of strategy. Based on this research, the researcher suggests that teachers be able to implement this strategy in education living environment learning.

Keywords: learning strategy; self-concept; environmental health education; problem based learning (PBL); elementary school 


\section{The influence of learning strategy resolution based toward environmental health learning result observed by students' concept}

\section{Introduction}

School is an institution at which gathers many people and that has potential to produce waste (organic and inorganic) besides home industry and office complex. School is a believable medium to change paradigm, character and attitude of human being, especially in aspects of life such as economy, social, culture, technology and environment in order to support life and next generation. Therefore, an education institution supports socialization dealing with the concepts of environmental health education learning result, issue and environmental problem, along with its solution.

The environmental education can be an important institution or mean to gain child's information about environment formally or non-formally which could improve the knowledge and affect the mental (Young \& LaFollette, 2009). The result of environmental health education learning can be treated by teachers through environmental health education subject which is integrated on each subject. The competency treated can change attitude and understanding of students about waste and recycling. Teachers need to give explanation to students how today's action can determine the future, so that they will be eager to love and take care about the environment around them.

As State by UNESCO (1997), that environmental education is a permanent process in which students have awareness of their environment and acquire the knowledge, skills, experiences, and also the determination which will enable them to act individually and collectively to solve present and future environmental problems, as mentioned by Romiszowski (2004), the result of environmental health education learning is a number of information within mind of human being. Knowledge is distinguished to be factual and conceptual. The factual is in the form of (1) knowing the object phenomenon and human being; (2) knowing the procedure or what we should do in a certain situation. The conceptual knowledge is in the form of (1) a specific or group concept; (2) the concept of linking concepts and facts. Thus, the aspect of knowledge is distinguished into four, i.e. facts, procedures, concepts, and principles.

Waste recycling is an activity to reuse the waste through certain processes (reduce, reuse, recycle) to change its former function to be more useful. It has some advantages including keeping environment clean and giving economically giving benefit. The environmental health education learning topic on recycling consists of a factual knowledge, conceptual, procedural, and metacognitive, recycling for certain (reduce, reuse, and recycle). According to Alex (2010), waste is a material which is unused by human activity or natural process which not has economic value. Waste is unused material, discarded by people or the first owner and waste is unused resource. Markak (2014) said that students could acquire the understanding if they are faced directly to the nature, observing by using their own senses. They are more closely to natural environment.

Kinds of waste are divided based on their trait, organic and inorganic. The organic or wet waste is originated from remains of living things such as leaves and kitchen recycling waste. This is easy to decompose naturally, whilst inorganic or dry waste is from the in decomposed such as rubber, plastic, cans, and metal. The management of the waste is easy to recycle. By this process we can understand the managed waste. The learning process developed by teachers in primary school curriculum is to improve understanding about the concept and facts. Teachers should give students a chance to be active and creative in a comfortable learning so that the process of learning and the result can be obtained optimally. Teachers should engage students in inquiry-based activities to encourage a deep understanding about science and to develop attitudes and social values conducive for science learning. PBL as a vehicle for teaching science in the elementary classroom has a potential to address these recommendations. 
The influence of learning strategy resolution based toward environmental health learning

The experience can be a source of learning. The students can get some information by problems they meet in daily life and many conditions. It also can affect students' motivation to be more active (Bayrak \& Bayram, 2011). The use of learning strategy should be easy for students to develop their thinking skill. Providing good learning resource and innovative learning strategy is needed to improve students' understanding in relation with recycling of the waste in environmental health subject. The learning strategy is important for students to think creatively, based on primary school curriculum; it is needed by the teachers to run an innovative learning strategy, for instance, the strategy of learning based on constructivism. Constructivism is a process to establish and to arrange a new knowledge within cognitive aspect of students based on experience.

According to Harding (2001), the teacher is only proposing the problem or case to the students. The students are active to discover the findings. In PBL, teacher is not a source to find the answers; he is just the facilitator and mentor. In PBL environments, learning is entirely focused around solving an authentic problem, which is often presented in a case. And in contrast to traditional pedagogies, learners do not learn the "basic" first and in a separate, often inauthentic mode (for example, read "about" a theory or a model rather than use it); rather, they learn basic content in the context of solving the complex, authentic problem (Jonassen et al., p. 243).

Environmental health education in North Jakarta exactly in SDN Tugu 01 has been recommended through environmental health subject in grade V and VI. The learning process in the classroom conducted in one session consists of two hours within $2 \times 40$ minutes per week both in and off class. The fact shows that students are not aware of the benefit of waste recycling, both organic and inorganic. It can be seen in the school environment that a lot of waste scatters, students keep the waste inside drawers. Students have not yet understood the benefit of environmental health for the school.

The learning process of environmental health in the classroom that requires being teacher-centered in its process by making use of limited references prepared does not improve significantly. Furthermore, this is also worsened by teacher's low understanding in using good learning strategy for teaching the subject.

\subsection{Research Question}

For the purpose of the study, the objectives were to obtain answers to following questions:

$>$ The difference of waste recycling knowledge between the one which is treated with problem-based learning strategy and with expository strategy;

$>$ The interaction between self-concept learning strategy and knowledge of waste recycling;

$>$ The difference of waste recycling learned through problem-based and expository strategies for students with low self-concept.

\section{Literature Review}

By making discussion with a small group is a main point in implementation of PBL. A real problem is a main guide to direct the PBL to stimulate the students to learn the problems based on their knowledge and experience. Students play an active role and use an iterative process of seeking new information based on identified learning issues, restructuring the information in light of the new knowledge, gathering additional information, and so forth. Faculty plays a facilitator role, not a traditional instructional role, by posing metacognitive questions to students.

One of efforts to increase learning result of health education of waste recycling and bring about environmental care for students through healthy environment learning is conducted by a learning strategy that can activate students namely a problem-based learning strategy. Viewed by a psychological learning aspect, a learning strategy based on problem lean on cognitive psychology which assumes that learning is a process of behavioral change because of a learning experience, not only a process of facts memorizing, but also a process of 
conscious interaction between the individual and the environment. Yulan (2014) mentioned that teacher or instructor direct and motivates the learners to be active by selecting a certain problem relates to the learning topic. The learners will see the problems based on their own prior knowledge and then selecting the reasonable issues and aspects to be more investigated.

Kim and Lee (2014) found that his study examined In PBL; the students are challenged to think critically and improve their skill to solve the problem as well as obtain the new essential knowledge and concept of the material. Current elementary students are required to develop information processing skill to create new knowledge for this digital age. There is, however, a shortage of learning strategies for these information processing skills. This research proposes a method for teaching information processing abilities based on a problem-based learning model which is tested on elementary students. The students developed an improved ability to create new knowledge and to present relationships of information through the process of problem solving. Wena (2011) said that problem-based learning strategy has some characteristics as follows: (1) learning starts from a problem, (2) a given problem should suit with students' real world, (3) organize learning around the problems not around study fields, (4) give a big deal of responsibility in forming and running their learning process directly and independently, (5) use a small group and (6) allow the students to demonstrate what they have learnt such as a product and performance.

With PBL, your teacher presents you with a problem, instead of lectures or assignments or exercises. Since you are not handed "content", you're learning becomes active in the sense that you discover and work with content that you determine to be necessary to solve the problem. In PBL, the teacher acts as facilitator and mentor, rather than a source of "solutions". Problem based learning will provide you with opportunities to examine and try out what you know discover what you need to learn and develop your people's skills to achieve higher performance in teams, to improve your communications skills state and to defend positions with evidence and sound argument to become more flexible in processing information and meeting obligations practice skills that you will need after your education. Learners are more closely adapting with real life, because contextual problem can give cognitive balance in which the learner will be eager to know the causes of the problems. They learn a real thing, happening, and experienced by them. Therefore the learner will obtain the advantage of learning for their life (Ramsay \& Sorrell, 2007).

The next learning strategy is expository; the term 'expository' derives from an exposition concept that means giving an explanation. In terms of learning, expository is a learning strategy that focuses on teachers where inventions of most information presented by teacher's deals with samples which are still abstract (Jacobsen, Eggen \& Kauchak, 1989). According to Vernon and Elly (1980), an expository learning strategy tends to stress on information presentation that is derived from text books, references or personal experience by using demonstration speech technique and study report. Besides using problem-based strategy in the learning of environmental health education, concept of students' themselves also needs to be considered. As mentioned by Jalaludin (2010), self-concept is a self-mental image from self-information, hope, and personal assessment. Self-concept is one of the factors that determine whether one behaves negatively or positively. Negative behavior is a reflection of one's incapability and sees the capability that he has and it is such a one's failure in establishing self-esteem. When someone is a one's failure in establishing failure in self-esteem so he will feel disappointed towards himself and his environment, he deems himself having no capability and looks himself negatively (Woolfolk, 2008).

Individual's negative attitude and view of his capability will have him fail to attain his best achievements. Otherwise, when someone succeeds in standing on his self-esteem, he thinks he is capable and will be satisfied with himself or his environment. It drives him to behave himself. One's positive attitude and view are encouraged to obtain good achievement as well. In psychology, according to Woolfolk (2008) self-concept commonly tends to be on individual's knowledge and confidence upon himself, ideas, feelings, and expectations. It is related to Carlson's notion (1997) that self-concept is someone's knowledge, feelings, and ideas towards themselves. In the process of environment health learning through a suitable learning strategy, students' positive self-concept would trigger students' care of waste recycling. Specifically, the purpose of this study is to know: 1. the difference of 
The influence of learning strategy resolution based toward environmental health learning

waste recycling knowledge between the one which is treated with problem-based learning strategy and with expository strategy; 2 . the interaction between self-concept learning strategy and knowledge of waste recycling; 3 . the difference of waste recycling learned through problem-based and expository strategies for students with low self-concept.

\section{Methodology}

This research used a design. Population of the research covered sixth grade students of 2012/2013 at SDN 01 Tugu Selatan, North Jakarta with students of Class VI B as the experimental and students of Class VIA as class control. The number of students (n) was 38 respectively. The independent variable of this research was two learning strategies (problem-based and expository). The dependent variable was result of environmental health education learning on waste recycling. The instruments used for collecting data in this research were; (1) testing instrument of the result of environmental health education learning on waste recycling; and (2) non-test instrument, a self-concept questionnaire. The research data was collected in even semester, academic year of 2012/2013. The research data was quantitative data like result score of environmental health education learning on waste recycling. The data analysis result was an implementation of problem-based and expository learning strategies towards the result of environmental health education learning of waste recycling. Analysis of variance (ANOVA) proceeded with Tukey test were employed for data analysis. Test of analysis requirements with Lillefors normality examination and Bartlett test of data homogeneity were performed prior to hypothesis examination. Statistics test was conducted on significant level of 5\%. Design of this research can be displayed on table 1 below.

Table 1

Design of experiment

\begin{tabular}{ccc}
\hline \multirow{2}{*}{ Self-concept $(\mathrm{B})$} & \multicolumn{2}{c}{ Learning strategy $(\mathrm{A})$} \\
\cline { 2 - 3 } & $\begin{array}{c}\text { Problem based learning } \\
\left(\mathrm{A}_{1}\right)\end{array}$ & $\begin{array}{c}\text { Expository learning } \\
\left(\mathrm{A}_{2}\right)\end{array}$ \\
\hline High $\left(\mathrm{B}_{1}\right)$ & $\mathrm{Y}_{11 . \mathrm{k} ; \mathrm{k}=1,2, \ldots, 10}$ & $\mathrm{Y}_{21 . \mathrm{k} ; \mathrm{k}=1,2, \ldots, 10}$ \\
& $\mathrm{~A}_{1} \mathrm{~B}_{1}$ & $\mathrm{~A}_{2} \mathrm{~B}_{1}$ \\
Low $\left(\mathrm{B}_{2}\right)$ & $\mathrm{Y}_{12 . \mathrm{k} ; \mathrm{k}=1,2, \ldots, 10}$ & $\mathrm{Y}_{22 . \mathrm{k} ; \mathrm{k}=1,2, \ldots, 10}$ \\
& $\mathrm{~A}_{1} \mathrm{~B}_{2}$ & $\mathrm{~A}_{2} \mathrm{~B}_{2}$ \\
\hline
\end{tabular}

\section{Results}

The summary of data analysis using two way ANOVA test can be displayed on table 2 below.

\section{Table 2}

Two Ways ANOVA

\begin{tabular}{cccccc}
\hline Source of Variances & Sum Square & $d f$ & Mean Square & $\mathrm{F}_{\text {count }}$ & $\mathrm{F}_{\text {table }}$ \\
\hline $\mathrm{A}$ & 55.23 & 1 & 55.23 & 10.56 & 4.11 \\
$\mathrm{~B}$ & 697.23 & 1 & 69.23 & 133.31 & 4.11 \\
Interaction A $\times \mathrm{B}$ & 119.02 & 1 & 119.02 & 22.75 & 4.11 \\
Error & 188.30 & 36 & 5.23 & & \\
Total & 1059.78 & 39 & & & \\
\hline
\end{tabular}

\subsection{Difference of students' environmental health education result between student which taught by problem based learning strategy and expository learning strategy}

The environmental health education score of students with high self-concept and treated with problem-based learning strategy is higher than that of students with expository learning strategy. Anova calculations result showed that the value of $F_{\text {count }}=10.56>F_{\text {table }}=4.11$ for $5 \%$ significance level, then $\mathrm{H}_{0}$ was rejected and $\mathrm{H}_{1}$ was 
accepted, it meant that there was a significant difference between the aplication of problem-based learning strategies and learning strategies expository result of environmental health about waste recycling. Empirically, based on data calculation of mean group $\mathrm{A}_{1}=19.60$ and mean group $\mathrm{A}_{2}=17.25$. Thus, results show that the mean of score students' environmental health education; which taught by problem-based learning strategies, was higher than mean of score students' environmental health education; who are taught with expository learning strategies.

\subsection{Interaction between learning strategy and self-concept toward students' environmental health education result}

There are interactions between learning strategies and self-concept through students' score in environmental health education on waste recycling. The result of testing hypothesis through the impact of learning strategy interaction and self-concept in students' score, based on the table, showed that $F_{\text {count }}=22,75>F_{\text {table }}=4.11$. Because the result is higher than the value table, the hypothesis $H_{0}$ was rejected and $H_{1}$ or research hypothesis was accepted, it means that the effect of interaction between the learning strategies and students' self-concept in students' score of in environmental health education on waste recycling does exists.

Chart of interaction between learning strategy and self-concept can be displayed on figure 1 below.

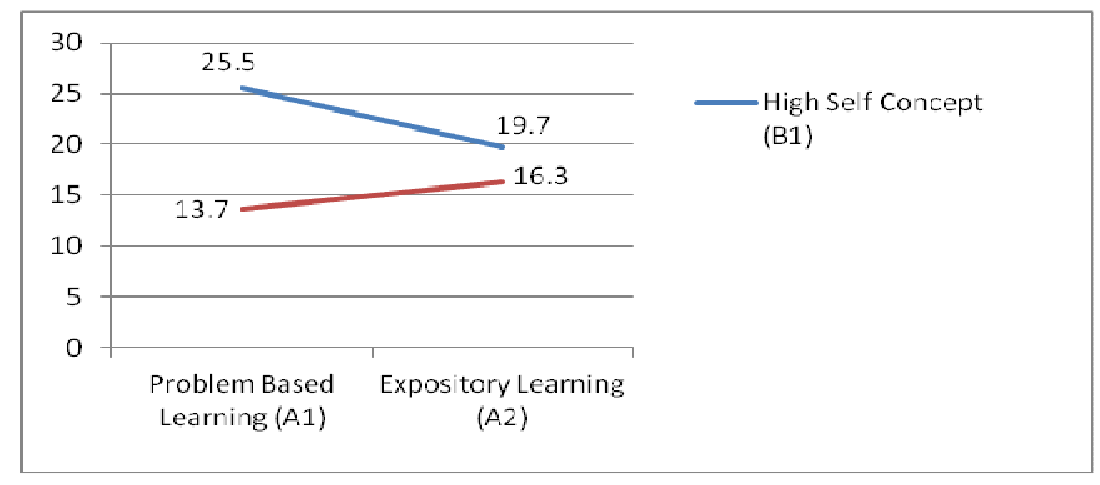

Figure 1. Figure of interaction between learning strategy and self-concept.

Because of that has influence learning strategy and students' self concept through students' score of environmental health education about recycling the waste, so with doing further test using Tukey test. Summary of test results can be seen in the following table.

Table 3

Summary of Data on Tukey Test Results

\begin{tabular}{cll}
\hline Testing Group & $Q_{\text {count }}$ & $Q_{\text {table }}$ \\
\hline$\mu \mathrm{A}_{1} \mathrm{~B}_{1}$ and $\mu \mathrm{A}_{2} \mathrm{~B}_{1}$ & 9.15 & 4.33 \\
$\mu \mathrm{A}_{1} \mathrm{~B}_{2}$ and $\mu \mathrm{A}_{2} \mathrm{~B}_{2}$ & 5.42 & 4.33 \\
\hline
\end{tabular}

\subsection{Difference of students' environmental health education result between student which taught by problem}

based learning strategy and expository learning strategy to students who have a high self-concept.

A difference exists between the environmental health education score on waste recycling of students with high self-concept and treated with problem-based learning strategy and that of students with expository learning strategy. Anova test show that the score of students with high self-concept and treated with Problem-Based Learning strategy is higher than that of students with expository learning strategy. Table 3 show that $Q$ count $=$ $9.15>Q_{\text {table }}=4.33$. There is a significant influence between the application of learning strategy with PBL and expository learning strategy in the score of environmental health education on waste recycling for students 
The influence of learning strategy resolution based toward environmental health learning

belonging to group of high self-concept.

\subsection{Difference of students' environmental health education result between student which taught by problem}

based learning strategy and expository learning strategy to students who have a low self-concept.

The score result in environmental health education of students with high self-concept and treated with problem-based learning strategy is lower than that of students with expository learning strategy. Anova test showed that the score of students with high self-concept and treated with problem-based learning strategy is lower than that of students' with expository learning strategy. Table 1 showed $F$ count is higher, Table 3 show that $Q$ count $=5.42>Q_{\text {table }}=4.33$. There is a significant influence between the application of learning strategy with PBL and expository learning strategy in the score of environmental health education on waste recycling for students belonging to group of low self-concept.

\section{Discussions and Implications}

\subsection{Discussions}

A. The difference of students' result learning environmental health education about waste recycling who got a treatment with based problem learning strategy and expository learning strategy.

The results of hypothesis testing explain that the difference found in the learning environmental education on waste recycling and in the application of problem-based and expository learning strategies could be accepted. In this case, the mean score of students with problem-based learning strategy is significantly higher (19.60) compared with that of students with expository strategy (17.25). It proves that the problem-based learning strategy provides an opportunity for students to learn for themselves and develop their intellectual self-development potential in learning activities. According to Howard (2002), PBL is a development of curriculum and teaching system which focus at students to solve the problem in their real life by using their knowledge and skill. In all learning conditions are directed to contextual thing.

Problem-based learning strategy focuses on students' problem solving. Problem-based learning strategy is an approach to develop the structure of the curriculum that involves students to face the problems with exercises that provide a stimulus for learning (Eggen \& Kauchak, 2007). In the Problem-Based Learning (PBL), the learning atmosphere is more relaxed because the children are not limited by the walls of the classroom. They learn outside the classroom and directly contact with the object being discussed. It is fun because the students see the object directly and make a note things related to the subject. It can train students' ability to think critically and creatively. In the end, the students are expected to have a caring nature towards the environment and can make alternative problem solving through principle of $3 \mathrm{R}$. This method promotes environmental health education to be long lasting learning in its result.

It is supported with a research by Lehman and Burcin Acar-Sesen (2013) noted that PBL can affect positively in improving students' achievement because PBL can direct the students to use the cognitive skill. It is stimulating the students to think higher how to solve the problems. The students think independently to discover the concepts relate to the material. PBL can create social system which can be a democracy characteristic and scientific process. The students can practice how to respond the development of social dynamic. It is the development of group learning. The results support that if PBL is more widely used in a science class, it seems that students will be able to achieve the skills that they need for their success in life. For this reason, despite some problem found in PBL, its advantages should be considered for the success of education.

PBL strategy has enjoyed worldwide research and has been in some cases revealed to promote students' social skills, motivation, and interest in the subject matter. While PBL has been researched into and very well documented as an effective strategy in one hand for enhancing students' learning outcomes in varied school 
subjects across many countries in Europe, America, Asia, and Africa (Fatada et al., 2014).

Learning by using expository strategy is more focused on teacher's ability to explain the material verbally for students to understand (Smith \& Ragan, 1993). After the teacher explains the subject, students are asked to form small groups for discussion. Issues discussed in the group are taken from slides or pictures on the types of waste recycling that has been provided by the teacher, and students in groups are asked to identify and look for alternative solutions. In the expository strategy, the learning conditions are more serious; the students concentrate to identify the problems through pictures, and then taught to find alternative solutions. Students are required to memorize the concepts or facts or data so that it does not require students to think further. This method may lead to short lasting result in the health education learning. It means that the problem-based learning strategy is more effective in improving the learning results of environmental health education on waste recycling, when compared with expository learning strategies.

B. The Interaction effect of learning strategies and self-concept together on learning results of health education on waste recycling.

Selection of problem-based learning strategies and expository strategy, based on the characteristics of the self-concept of students give high and low impact on the learning results of environmental health education on waste recycling. Students with a high self-concept and treated with problem-based learning and expository learning strategies can improve the learning result of environmental health education on waste recycling. However, the problem-based learning strategy results better than expository learning strategy. The students with low self-concept and treated with expository strategy can improve the learning result better than those treated in problem-based learning strategy. It is shown at the average value of 25.50 obtained by the group of high self-concept with problem-based learning and of 19.70 with expository strategy.

Meanwhile, the group of low self-concept obtains an average value of 13.70 with a problem-based learning and of 14.80 for expository learning strategy. Thus, based on the rates above, it can be concluded that the higher self-concept of students, the higher value of learning results obtained, on the contrary, the lower self-concept of students, the lower value of learning results. In this research, based on the average value obtained, there is a difference between both learning strategies. This case shows that the strategy of problem-based learning is more effective in improving the learning results of environmental health education. Effectiveness of problem-based learning strategy is also determined by the student's self-concept. Students with high self-concept can be treated with expository learning strategies and problem-based learning. While students with a low self-concept would be better if treated with expository teaching strategy because students can hear through the narrative and see through the implementation of the demonstration.

According Biggs and Watkins (1995) that low self-concept is related to academic failure and that would boast their success in a school test or won a popularity contest, ten that would boost their self- esteem. It means that the use of appropriate learning strategies and students' self-concept will affect the learning results.

C. The differences of learning result of health education on waste recycling through problem-based learning strategies and expository learning strategy, towards the group of students with high self-concept.

The students with high self-concept have sensitivity and concern about the environment, so that they will be able to learn by using problem-based and expository learning strategies of expository. However, learning by using Problem-Based learning strategies is very fun, students enjoy the learning activity because it so easy to understand that the environmental health education learning results obtained stored longer in their memory. That is because students learn directly, by looking at the object itself, engaging directly with nature, discover and perform activities related to the learning material. Therefore, students learn with all of their senses, involving cognitive, affective and psychomotor. 
The influence of learning strategy resolution based toward environmental health learning

As state by Bas (2010), the teacher should select an appropriate learning strategy for his teaching and learning. Sometimes the teacher use monotonous strategy that is focused on teacher. By using PBL is one of an effective strategy in learning because improving the way of thinking, intellectual skill, act as an adult through real condition or simulation learning, and be autonomous learner.

While the learning atmosphere of the expository is more serious condition, students concentrate on memorizing the concepts or factor data that does not require students to think further. This learning method makes environmental health education learning results obtained by students not to last long. It means that, students treated by using a problem-based learning strategy results higher when compared with those treated with expository learning strategies. It is shown at the average value of 25.50 obtained by the group of high self-concept with problem-based learning and of 19.70 with expository strategy.

D. The difference between environmental health education result on waste recycling through Problem-Based learning strategy and expository learning strategy at group of students with low self-concept.

For students with low self-concept, learning activity through problem-based learning strategy is difficult, because this strategy drives students to think systematically and scientifically, in consequence, they become slow and less enthusiastic in learning activity. They feel hard to understand materials through a discussion to solve a problem, because they are claimed to think hard to explore whole knowledge in their brain, to identify kinds of waste, to investigate the alternative problem solving. Strategy of learning problem solving is difficult, so that it influences the mastery of learning environmental health education that always shows low. However, students with low self-concept could follow learning activity with expository strategy because this strategy does not demand students' ability to criticize, the most important is that students are ready to do exercises according to teacher's direction and look what is demonstrated by the teacher. Through teacher's direction and advice, the low self-concept students could follow learning activity happily, comfortably, and master waste recycling material better. Learning activity with expository strategy in a group of low self-concept student is better than that of problem solving strategy. That case reads in all scores that students with low self-concept score 13.70 in the latter strategy but 14.80 in the former.

\subsection{Implications}

Students' score data is analyzed by using Analysis of Variance (ANOVA) followed with Tukey Test $(Q)$ ), to observe the interaction between research variables. Based on the result of hypothesis test, it can be concluded as follows:

$>$ In general, the result of students treated with problem-based learning and expository learning strategies have a significant difference. It is pointed out by $F$ count result analysis that shows bigger than $F$ table $(10.56>4.11$ to $0.05>7.40$ to 0.01$)$.

$>$ An interaction is investigated between learning strategy, self-concept, along with the result of environmental health education on waste recycling. Based on the variance result analysis, $F$ count is bigger than $F$ table $(22.75>4.11$ to $0.05>7.40$ to 0.01$)$.

$>$ It is shown that students with high self-concept and treated with both problem-based and expository learning strategies result higher than students with low self-concept. Students with low self-concept treated with problem-based learning strategy results lower than those with expository learning strategy. It is pointed out by the variance result analysis where $F$ count is bigger than $F$ table $(133.31>4.11$ to a $0.05>7.40$ to a 0.01 ). It means that a significant difference exists between the result of environmental health education learning for both students with high and low self-concept when treated with both Problem-Based and expository Learning strategies. 
Based on findings, it could be summarized that all results of environmental health education show higher when students are treated with problem-based learning strategy than those with expository learning strategy. The students with high self-concept and taught with problem-based learning strategy results higher than those with expositroy learning strategy. The students with low self-concept and treated with problem-based learning strategy results lower than those with expository learning strategy. An interaction between learning strategy and self-concept towards students' result does exist.

Based on the explanation above, some implications are summed up as follows:

$>$ Problem-based and expository learning strategies with their respective characteristics will increase students' competence when it suits the subject matter. Problem-based learning strategy is more efective to increase the result of learning health environmental education than the expository learning strategy, therefore, the teachers can use them in learning the environment through school extracurricullar activities, they can make form unit of environmental activities and manage school environment, provide extension about the importance of minimizing the waste with $3 \mathrm{R}$ principles, make competetion, composting and handicraft by utilizing the waste in school.

$>$ It is expected to promote students' awareness and develop positive attitude towards environment to become a good habit for students.

> The Ministry of Education and Culture is expected to facilitate the environmental book publications, both as a guide for teachers and students handout.

\section{References}

Alex. (2011). Sukses mengolah sampah organik menjadi pupuk organik [Successful process organic waste into organic fertilizer]. Yogyakarta: Pustaka Baru Press.

Bas, G. (2010). The effects of multiple intelligences instructional strategy on the environmental awareness knowledge and environmental attitude levels of elementary students in science course. International Electronic Journal of Environmental Education, 1(1), 64-75.

Bayrak, B., \& Hale, B. (2011). Effects of problem-based learning in a web environment on conceptual understanding: The subject of acids and bases. International Online Journal of Educational Sciences, 3(3), 831-848.

Biggs, J., \& Watkins, D. (1995). Classroom learning: Educational psychology for the Asian teacher. Singapore: Prentice Hall.

Carlson, N. R. (1977). Psychology: The science of behavior. Boston: Allyn and Bacon.

Eggen, P., \& Kauchak, D. (2007). Educational psychology. New Jersey: Pearson Hall.

Fatada, A. O., Arigbabu, A. A., Mogari, D. M., \& Awofala, O. A. (2014). Investigating senior secondary school student' beliefs about further mathematics in a problem based learning context. Bulgarian Journal of Science and Education Policy (BJSEP), 8(1), 9-10.

Gerlach V. S., \& Elly, P. D. (1980). Teaching and media: A systematic approach. New Jersey: Prentice Hall. Harding, J. E. (2001). Problem-based learning in biblical studies: Reflections from classroom experience. Teaching Theology and Religion, 4(2), 89-97. http://dx.doi.org/10.1111/1467-9647.00099

Howard, J. (2002). Technology-enhanced project-based learning in teacher education: Addressing the goals of transfer. Journal of Technology and Teacher Education, 10(3), 343-364.

Jacobson, D., Eggen. P., \& Kaucheack, D. (1989). Methods for teaching: A skill approach. Columbus, Ohio: Merrill Publishing Company.

Jalaluddin, R. (2003). Psikologi komunikasi [Communication psychology]. Bandung: Remaja Rosdakarya.

Kim, D. G., \& Lee, J.-M. (2014). A study on improving information processing abilities based on problem based on PBL. Turkish Online Journal of Distance Education, 15(2), 41-51.

Kuo, F. R., \& Hwang, G. J. (2014). A five phase learning cycle approach to improving the web-based problem 
The influence of learning strategy resolution based toward environmental health learning

solving performance of students. Educational Technology \& Society, 17(1), 169-184.

Kanter, L. S. (1998). Fundamental concepts of problem-based learning for the new facilitator. Retrieved from http://www.ncbi.nlm.nih.gov/pmc/articles/PMC226387

Lehman, T., \& Burcin, A. S. (2013). Problem based learning in acid and based: Learning achievement and students believed. Journal of Baltic Science Education, 12 (5), 565-578.

Marra, R., Jonassen, D. H., Palmer, B., \& Luft, S. (2014). Why problem-based learning works: Theoretical foundations. Journal on Excellence in College Teaching, 25 (3\&4), 221-238.

Romiszowski, A. J. (2004). Producing instructional systems. New York: Nicholas Publishing.

Ramsay, J. \& Sorrell, E. (2007). Problem based learning. Professional Safety, 52(9), 41-46.

Smith, P, L., \& Tillman, J. R. (1993). Instructional design. New York: Macmillan Publishing Company.

UNESCO Institute for Education. (1997). Adult environmental education: Awareness and environmental action confintea. Retrieved from http://www.unesco.org/education/uie/6a.pdf

Wena, M. (2011). Strategi pembelajaran inovatif kontemporer [Contemporary innovative learning strategies]. Jakarta: Bumi Aksara.

Vassiliki, M. (2014). Environmental education through inquiry and technology. Science Education International, $25(1), 86-92$.

Woolfolk, A. (2008). Educational psychology. Boston: Allyn and Bacon.

Young, R. M., \& LaFollette, S. (2009). Assessing the status of environmental education in Illinois elementary schools. Environmental Health Insights, 3, 95-103.

Yuan, Y. (2014). Improving undergraduate student awareness of tourism impacts and responsible travel behaviors through problem-based learning: A qualitative study. Sustainable Environment Research, 24(3), 201-211. 
